\title{
Kerkgroei: 'n Kritiese evaluering van die kernaspekte van die Church Growth Movement
}

Ds. Flip Buys.

\section{AKTUALITEIT VAN DIE ONDERWERP}

Daar is nie 'n sendingwetenskaplike rigting in die wêreld wat groter en invloedryker is as die "Church Growth Movement" nie. Die U.S. Center for World Mission, onder leiding van Ralph Winter, wat in 1976 uit die "Church Growth Movement" ontstaan het, en wat die beskouings van die "Church Growth Movement" die sterkste wêreldwyd propageer, is ingerig op 'n voormalige universiteitskampus in Pasadena, Kalifornie. Dit beslaan 'n grondgebied van 35 akkers, en is die grootste instelling in die wêreld wat hom beywer vir sendingwetenskaplike navorsing en ondersteuning van sendingprojekte. Kantoorruimte, klaskamers, rekenaarfasiliteite, 'n biblioteek, slaapsale en ander bates is reeds meer as 25 miljoen dollar werd. Sendelinge van sewentig verskillende denominasies en genootskappe werk reeds daar saam in navorsingsprojekte en gevorderde opleiding en mobilisering van sendelinge. Die oorheersende doel is om teen die jaar 2000 die sendingtaak van die kerk voltooi te sien in dié opsig dat daar Christelike kerke onder al die 17000 onbereikte volksgroepe van die wêreld tot stand gekom het. (Vgl The U.S. Center for World Mission, 198?).

Dit is belangrik - en ook reg - dat die "Church Growth Movement" ook in Gereformeerde kringe steeds meer belangstelling wek:

1.1 In 'n sendingwetenskaplike proefskrif wat in 1983 onder leiding van proff. I. J. van der Walt en J. C. Coetzee aan die PU vir CHO verskyn het, word van McGavran, die stigter van die "Church Growth Movement", gesê: ". . . we need to note how thankful we should be to God for raising up a man like McGavran. He has been used by the Lord in pointing the way for the growth of the church of Jesus Christ in many parts of the world." (Son, 1983:255).

1.2 In Suid-Afrika het op dieselfde patroon as die Institute for Church Growth in Pasadena, Kaliforniè ook reeds - onder leiding van dr. Johan Engelbrecht - 'n Instituut vir Kerkgroei in Afrika ontstaan wat die basiese beginsels van die "Church Growth Movement" sterk propageer en op uitnodiging kursusse aanbied en gemeentes adviseer oor allerhande aspekte van kerkgroei.

So het dr. Engelbrecht onlangs vir 'n week lank 'n kursus wat deur die Gereformeerde Teologiese Vereniging van die Witwatersrand gereel is, vir 'n dertigtal predikante van die Gereformeerde Kerke in Suid-Afrika aangebied.

1.3 In 'n onlangse publikasie oor evangelisasie, uit die pen van 'n emeritus hoogleraar in Evangelistiek en Sendingwetenskap van die 
Gereformeerde Kerke in Suid-Afrika, word die "Church Growth Movement" deurgaans baie positief beoordeel (vgl. Van der Walt, 1985: 122-125). Sommige standpunte van die "Church Growth Movement" word selfs kritiekloos oorgeneem en as deel van 'n Gereformeerde benadering tot evangelisasie beskou. (Vgl. Van der Walt, 1985:14 waar sy kategorisering van ses vlakke van evangelisering in die geheel | sonder die nodige erkenning] van Ralph Winter (1975:230) oorgeneem word.)

1.4 In Gereformeerde kringe in Nederland word die "Church Growth Movement" met gemengde gevoelens bejeën. Iemand soos Bram Krol prys in sy werk en publikasies hierdie benadering geweldig aan en probeer dit in Nederlandse idioom vertaal. (Vgl. Krol 1982). Aan die ander kant is daar egter resensente wat meen dat Krol met die "Church Growth Movement" "op onze vaderlandse bodem een principieel nieuwe koers" aangewys het (Anon 1982).

1.5 Die Christian Reformed Church of North America het reeds in 1970 'n "Study Conference on Church Growth" gereel waar die "Church Growth Movement" krities oorweeg is en positiewe punte oorgeneem is. Arthur Glasser, die dekaan van die School of World Mission by die Fuller Theological Seminary, waaraan die Institute for Church Growth verbonde is, dui nege kernbeginsels van die "Church Growth Movement" aan wat vir hom in die lig van die Skrif en die Gereformeerde leer aanvaarbaar is (Conn, 1976:21-42).

Nadat die hersiene uitgawe van McGavran se "Understanding Church Growth" in 1980 verskyn het, het die "Board of Home Missions" van die Christian Reformed Church of North America 'n stuk met 11 punte van waardering en kritiek en die standpunte van die CRC ten opsigte van kerkgroei opgestel om gebruik te word as vertrekpunte in die advies en begeleiding wat aan plaaslike gemeentes ten opsigte van die kerk se roeping in die wêreld deurgegee word (vgl. Hart 1987).

1.6 Tydens die jaarvergadering van die Suid-Afrikaanse Werkgemeenskap vir Sendingwetenskap van 1986 is 'n voordrag gelewer oor die Church Growth Movement en was die bespreking nogal skerp krities (De Wet, 1986:85-100).

Hieruit is dit duidelik dat hierdie beweging nie net wêreldwyd groeiende invloed uitoefen nie, maar dat reformatoriese kerke en sendingwetenskaplikes in Suid-Afrika veral prinsipiële besinning oor hierdie beweging moet stimuleer. Die vrae wat deur hierdie beweging aan die orde gestel word, sal grondig vanuit die Skrif beantwoord moet word, terwyl daar ook eerlik hand in eie boesem gesteek sal moet word.

\section{ENKELE HISTORIESE GEGEWENS}

Dit is onmoontlik om die "Church Growth"-skool se denke goed te begryp en te evalueer sonder om iets te weet van dr. Donald Anderson McGavran en die historiese omstandighede wat gelei het tot die ontstaan van die "School of Church Growth" in Pasadena, Kalifornië. McGavran het na vyfen-dertig jaar ervaring as sendeling in Indie 'n 
boek gepubliseer met die titel: "The Bridges of God". Die boek was 'n blitsverkoper en McGavran se gedagtes het baie bekend geword.

Een van die belangrikste stellings in hierdie boek het 'n hoeksteen van McGavran en die "Church Growth Movement" se denke geword: "The era has come, when Christian missions should hold lightly all mission stationwork, which cannot be proved to nurture growing churches, and should support the Christward movements within peoples as long as they continue to grow at a rate of 50 per cent per decade or more. This is today's strategy" (McGavran, 1955: 109).

Hierdie kardinale stelling in McGavran se denke moet teen 'n wyer agtergrond van die sendinggeskiedenis van die twintigste eeu verstaan word.

Gedurende die dertiger-en veertigerjare van hierdie eeu het die sending in baie dele van die wêreld sterk aangeleun op sendingstasies met hospitale, skole, en allerlei ontwikkelingshulpprojekte, wat grootliks met buitelandse kapitaal in stand gehou is. Van die vyftigerjare af het die lande van die Derde Wêreld al meer selfregerend geword en die regeringsmag en -gebiede van Westerse lande afgeneem. Dit het daartoe gelei dat Westerse sendelinge al moeiliker toegang begin kry het tot sendinggebiede in die Derde Wêreld. Baie sendingstasies is geplunder, en sendingskole en hospitale is afgebrand. Dit het tot pessimisme op sendinggebied en 'n heroorweging van sendingstrategie gelei.

In die sestigerjare het die ekumeniese beweging al sterker op die voorgrond begin tree. Op sendingterrein het die ekumeniese beweging gelei tot ' $n$ nivelering van grense, en 'n veel groter klem op noodleniging en die verandering van sosiale en politieke strukture as deel van die kerk se sendingtaak.

In hierdie tyd het die navorsing van biskop Pickett, wat die grootskaalse reaksie van ongelowiges deur middel van groepsbeslissings aangedui het, 'n groot indruk op McGavran gemaak (McGavran, 1980:46, 284 en 339) . In wat later al meer die "groot sendingdebat" geword het, het McGavran hom sterk teen die beklemtoning van die Uppsalavergadering van die Wêreldraad van Kerke uitgespreek. Hy kon selfs beweer dat Uppsala die twee miljard ongelowige mense wat daar nog in die wẻreld is, verraai het omdat die klem op "the word of service, and the visible Word of Christian unity", nie eers meer die intensie gehad het om mense tot geloof in (nristus te lei nie (McGavran, 1968:10). Die krisis in die sending is volgens hom dat daar te min aandag gegee word aan die stigting van gemeentes en die bewaring en vermeerdering van gemeentes.

Reeds in 1961 rig McGavran dan die "Institute of Church Growth" op wat sedert 1966 in Pasadena as onderdeel van die Fuller Theological Seminary bestaan. In 1970 is McGavran se magnus opus "Understanding Church Growth" gepubliseer en in 1980 verskyn 'n hersiene uitgawe waarin McGavran se kerkgroeibeginsels wat aanvanklik slegs op buitelandse sendingsituasies toegepas is, nou ook op gevestigde kerke in die Eerste Wêreld toegepas word. In 1984 sê Peter Wagner van hierdie publikasie: "It is and will long be the principal and indispensible textbook for the Church Growth Movement" (Wagner 1984:16) en dit is selfs al die "Bybel" van hierdie beweging genoem (Krol, 1982:8). Die blad 
"Global Church Growth Bulletin" wat deur die Instituut uitgegee word, word vandag wēreldwyd gelees.

Omdat die woorde "sending" en "evangelisasie" so baie bybetekenisse en verskillende nuanses ontvang het, het McGavran die term "kerkgroei" (church growth) geskep. Met die term wil hy alle aspekte dek wat sowel die bewaring as die vermeerdering van die kerk direk raak. Peter C. Wagner, die opvolger van McGavran, definieer kerkgroei so: "Alles wat nodig is om manne en vroue wat geen verhouding met Christus het nie, in gemeenskap met Hom en tot verantwoordelike lidmaatskap van die kerk te bring" (Wagner, 1984:14).

Die teologiese, maar veral die sosiologiese aspekte van kerkgroei word bestudeer en daar word geweldig baie van allerlei statistieke gebruik gemaak om die effektiwiteit van kerke se groei te meet. 'n Stortvloed van publikasies het reeds die lig gesien en seminare in verband met allerlei aspekte van kerkgroei word gereeld regoor die wêreld gehou. By baie Teologiese Skole word "Kerkgroei" reeds as teologiese dissipline gedoseer.

\section{McGAVRAN SE TEOLOGIESE UITGANGPUNTE}

McGavran se teologiese wortels lê in die "Christian Church of Disciples of Christ", 'n restourasiebeweging wat vroeg in die negentiende eeu gesamentlik in Skotland en die vSA ontstaan het. Aanvanklik was hierdie beweging veral gekant teen alle vorme van bekrompe kerkisme. Glasser sê daarvan: "At its heart was a passion for the unity for the body of Christ, an abhorrence of party spirit, and a deep conviction that no unity could be achieved until the life and faith and order of the New Testament Church were restored"' (Conn, 1976:23).

Alhoewel hierdie beweging en McGavran self, hoe waardering het vir die reformatore van die sestiende eeu se Skrifgebondenheid en die "solo Christo" van die Reformasie, was McGavran van mening dat die reformatore so 'n groot klem gelê het op die leer dat God die Outeur en Inisieerder is van die mens se redding en bekering, dat veral die opvolgers van die Reformasie hierdie groot waarhede op 'n goedkoop manier so omgebuig het, dat dit die fondamentstene van 'n introverte kerkisme geword het, waarvolgens die geïstitueerde kerk 'n doel op sigself geword het. Glasser sê hiervan: "Much of McGavran's theologising focuses on this introverted churchism" (Conn, 1976:24).

McGavran is van mening dat die sentrum van die kerk se taak die proklamasie van die evangelie is, die vergadering van die wat tot bekering gekom het in bestaande gemeentes en die vermenigvuldiging van nuwe gemeentes - kortliks, die uitbreiding van die "Church movement" met behulp van enige moontlike middel (Conn, 1976:26).

McGavran meen dan ook dat die meeste kerklike belydenisskrifte heeltemal te kort skiet daarin dat hulle nie genoeg die missionêre taak van die kerk sentraal stel nie. Hy meen dat die leer van die kerk meer Bybels sal wees as dit meer missioner gerig sal raak. "Each doctrine should drive Christians and Churches out to the evangelization of the three billion" (Conn, 1976:25). 


\section{TEOLOGIESE BEGINSELS TEN GRONDSLAG VAN DIE CHURCH GROWTH MOVEMENT}

Vir die aard van hierdie artikel word nou agtereenvolgend slegs kernbeginsels ten grondslag van die "Church Growth Movement" aangedui en op prinsipiele gronde geevalueer.

\subsection{God wil he verlorenes moet gevind word}

McGavran word nooit moeg om telkens te beklemtoon dat dit die geopenbaarde wil van God is, dat verlore sondaars nie net gesoek moet word nie, maar inderdaad gevind moet word. Almal wat nog nie gekom het tot 'n "redemptive relationship to Jesus Christ" nie, is nog verlore. Die Here het geen behae daarin dat sommige van sy skape wat gevind kan word, nog ronddwaal op die berge en bewe in die ysige winde nie. "The more found, the better pleased is God" (McGavran, 1980:32).

Sterk uitsprake in hierdie verband is die volgende: "Among other desires of God-in-Christ, He beyond question wills that persons be found - that is, be reconciled to Himself. Most cordially admitting that God has other purposes, we should remember that we serve a God Who finds persons. He has an overriding concern that men should be redeemed" (McGavran. $1980: 24$. kursief van McGavran).

Met beroep op Matt 9 : 37 oefen McGavran skerp kritiek uit teen 'n "Search Theology" en meen dat die kerk moet uitgaan van 'n "Harvesting Theology". "Indeed, any formula which limits the Christian to search, maintenance, or neutralist witness, whether out of respect for the sovereignty of God, or fear of practising religious imperialism has an artificial ring to it" (McGavran, 1980:34).

In die lig hiervan moet die kerk nie maak asof getalle onbelangrik is nie en niks te doen het met die kwaliteit van 'n gemeente nie. "The revelation of God throughout assumes that the numbers of the redeemed do count. It believes for example that as grace extends to more and more people, thanksgiving to the glory of God increases (II Cor 5 : 15)" (McGavran, 1980:36 en 37, kursief van McGavran).

Hierdie belang van syfers, getalle en statistieke en die verweefdheid van kwantiteit en kwaliteit, is 'n baie belangrike uitgangspunt in die "Church Growth Movement" se denke. Ralph Winter, die direkteur van die US Center for World Mission, meen dat dit 'n valse probleemstelling is om kwaliteit teen kwantiteit kerkgroei af te speel. Hy wys daarop dat goeie kwaliteit volgens Jesus juis gemeet word aan die kwantiteit vrugte wat opgelewer word (McGavran, 1972:175).

\section{EVALUERING}

Die klem wat McGavran en die "Church Growth School" daarop lê om evangelisering en sending sentraal te stel in die aktiwiteite van die kerk is 'n noodsaaklike - en by baie Gereformeerde Kerke ' $n$ dikwels verwaarloosde - waarheid. Telkens stel die Nuwe Testament dit as een van die redes waarom God die kerk in aansyn roep, naamlik om draer van sy heil vir die wêreld te wees (vgl. bv. Joh $20: 20$ en 1 Pet $2: 9$ ).

Dit is egter jammer dat hierdie Bybelse waarheid in die "Church Growth School" se denke soms so eensydig beklemtoon word dat gegewens soos 1 Tim 3 : 15, dat die kerk ook die doel het om pilaar en grondslag van 
die waarheid te wees en Heb $12: 14$, om heiligheid na te jaag byna nie funksioneer in hierdie teologie nie. Dit verklaar ook McGavran se skerp kritiek teen bestaande belydenisskrifte.

Die optimisme dat die kerk nie tevrede mag wees met 'n "Search Theology nie", maar in die geloof ook die verwagting van sukses en 'n "Harvest Theology" moet openbaar, is boeiend. Dit is inderdaad waar dat Gereformeerde kerke soms laksheid en oneffektiewe optrede t.o.v. sending en evangelisering met 'n skynvorm en fatalistiese beroep op God se soewereiniteit probeer goedpraat. In hierdie verband het I. J. van der Walt opgemerk: " 'n Eensydige selfgerigte introverte verkiesingsbegrip lei tot traagheid en belangeloosheid oor die lewe en lot van ander verbondskinders" (Van der Walt, 1982:5).

Tog is die "Church Growth"-teologie hieroor te eensydig. Dit is jammer dat gegewens soos 1 Kor 3: 6, waar Paulus uitdruklik stel dat hy tevrede was om net maar te saai, en dat God alleen die groei kan gee, nie verdiskonteer is nie.

John Young het dan ook tereg in sy kritiek teen McGavran se "Harvest Theology" daarop gewys dat die werk van die Heilige Gees nie deur McGavran in sy teologie genoegsaam erken word ten opsigte van die sendeling se vind en oorreding van mense tot die ewige lewe nie (Conn. $1976: 61)$.

Die groot belang van statistiek as middel om die kwaliteit van sendingwerk te evalueer kan gerus deur Gereformeerde kerke meer in ag geneem word. Die weerstand teen syfers en statistiek is dikwels 'n soort volstruispolitiek wat nie die leemtes en oneffektiwiteit van arbeid eerlik in die gesig wil staar nie. Tog is daar by die "Church Growth" skool ook hier eensydighede. Die Bybel maak dit baie duidelik dat getroue evangeliebediening finaliter nie net aan die aantal bekeerlinge gemeet mag word nie, omdat die evangelie vir sommige ook 'n reuk van die dood tot die dood is (2 Kor $2: 16$ ). God kan immers ook verheerlik word daarin dat die oordeel oor verworpenes dubbel so swaar is as hulle die evangelie verwerp het en sy geregtigheid seëvier. Trouens dit skyn asof die gerig van God en die regverdigheid en heiligheid van God nie in die konsep van 'n "Harvest Theology" funksioneer nie en daarom word die indruk van oppervlakkigheid gewek.

\subsection{Konsentreer op ontvanklike mense en groepe}

Met 'n beroep op Matt $10: 4$ en paralelle en Hand $13: 51$ het McGavran sterk nadruk daarop gelê dat die kerk hom moet toespits op mense wat ontvanklik is vir die evangelie en nie onnodig tyd en geld moet vermors op mense en gebiede wat duidelik in verset is teen die evangelie nie. "It is a fair inference that this was the common practice of the New Testament Church. It did not badger and bother people who resisted the Good News, but hurried to those who were ready to become believers" (McGavran, 1980:33).

Wagner brei hierop uit en is van mening dat daar in die Nuwe Testament 'n "Law of pruning" onderskei kan word. Hiervoor beroep hy hom op die gelykenis van die onvrugbare vyeboom in Luk $13: 6$ - 9 en meen dat bepaalde sending- en evangeliseringsaksies na 'n vasgestelde tyd laat vaar moet word as daar nie beduidende vrug kom nie, net soos die on- 
vrugbare vyeboom uitgetrek sou word as dit nie vrug dra nie. "Missionaries would do well to apply this principle of trial and error to all their work ... The mobility necessary to leave unfruitful works after an adequate trial period and move on to fruitful works would do a great deal to increase the evangelistic effectiveness of many missions" (Wagner, 1971:44).

Gereformeerde ondersteuners van hierdie beginsel, meen dat dit juis blyke gee van 'n nederige onderwerping aan die soewereiniteit van God en die ootmoedige en geduldige navolging van die leiding van die Heilige Gees om hierdie beginsel in die praktyk toe te pas (Conn, 1976:57).

Wagner maak hierdie beginsel ook van toepassing op strategieë en metodes in die kerk se uitoefening van sy evangeliseringsroeping. Bepaalde programme wat op bepaalde tye goeie vrug oplewer kan na ' $n$ tyd verouderd en uitgediend raak en dan moet sending- en evangelisasiewerkers 'n fyn aanvoeling hẽ vir die leiding van die Heilige Gees om sulke programme en metodes te laat vaar en iets nuuts op die proef te stel (Wagner, 1984(a):33 en Conn, 1976:45).

"Church Growth eyes" moet ontwikkel word om ryp en ontvanklike oeslande raak te sien.

Kommentaar

Dit is volkome juis dat die kerk sensitief moet wees vir die leiding van die Heilige Gees wat betref terreinafbakening, strategie en metodes in sending en evangelisasie. Dit is ook nie verkeerd om die leiding van die Heilige Gees daarin te sien wanneer bepaalde deure vir die kerk toegaan en ander weer oopgaan nie.

Paulus het ook in sekere situasies daarop gewys dat die Heilige Gees hom verhinder het om bepaalde sendingplanne uit te voer (Rom $1: 13$ ). Daar moet egter op gewys word dat die deur vir subjektiwisme en pragmatisme wawyd oop is wanneer daar nie deeglik mee rekening gehou word dat die Heilige Gees ons in die eerste plek ten opsigte van strategie lei deur Skrifbeginsels nie. Daarom is dit jammer dat die hele saak van die praktiese alledaagse leiding van die Heilige Gees in die lewe van die kerk ten opsigte van strategiee nie met deeglike eksegetiese onderbou verder teologies uitgewerk word nie. Daarom word die indruk gewek dat allerlei pragmatiese oorwegings en die vraag: "werk dit?" meer deurslaggewend is as 'n ootmoedige luister na die Skrif. (Tydens die kerkgroeiseminaar wat Johan Engelbrecht vir die GTV van die Witwatersrand in Johannesburg aangebied het, was daar dan ook van die kant van die Gereformeerde predikante heelwat vrae gevra oor die leiding van die Heilige Gees en gewaarsku teen subjektiwisme.)

Wagner se toepassing van die gelykenis van die onvrugbare vyeboom (Luk $13: 6$ - 9) laat nie reg geskied aan die werklike punt van die gelykenis in die lig van die konteks waarin dit voorkom nie, daarom word die boodskap van die gelykenis te ver gestrek om te sê wat nie werklik die intensie daarvan is nie. Dit gaan in die gelykenis in die eerste plek om Jesus se waarskuwing aan Israel oor God se naderende oordeel oor hulle omdat hulle sy genade en besondere bemoeienis met hulle verag het. Daarom is dit ' $n$ waarskuwing vir 'n ontroue kerk wat nie vrugdra nie en nie ' $n$ aanbeveling dat die kerk self op 'n stadium moet ophou 
om die Woord te bring vir mense wat nie wil reageer nie.

Daar moet ook veel meer gesē word van die praktiese implikasies van Matt $10: 14$ en Hand $13: 51$ vir sendingstrategie. Wanneer presies skud die verkondiger die stof van sy voete af? Daar bestaan immers ook die gevaar van 'n sondige gebrek aan volharding (2 Tim 4:2) en 'n tou opgooi met die werk voordat dit die Here se wil is. Dit lyk asof ons eers die stof van ons voete mag afskud as dit fisies onmoontlik geraak het om aan te hou met evangeliseringswerk. Dan eers mag ons sê dat die Heilige Gees werklik die deure toegesluit het.

\subsection{Sendingwerk is kerkwerk}

McGavran en die "Church Growth Movement" beklemtoon baie sterk dat sending en evangelisering moet uitgaan van die gemeente en dat mense wat as vrug daarvan tot bekering kom aktiewe verantwoordelike lidmate van 'n pliaslike gemeente moet word. Dit is een van die sterk kernbeginsels var die "Church Growth"-denke. Arn stel dit so eksplisiet: "The closer evangelism is integrated into a local church, the greater will be the fruit that remains" (McGavran \& Arn, 1973:11).

Daarom is dit wesentlik ' $n$ onmisbare aspek van kerkgroei om nuwe lidmate werklik tuis en deel te laat word van die plaaslike gemeente. "The same love and caring that brings people into any church must be exercised by groups within the church so that newcomers really become 'one of us'. The new person has to be 'grafted' into some group in the church, and that takes doing" (McGavran \& Arn, 1973:87).

McGavran se skerp kritiek teen sendingstasies en die opheffing van allerlei sosiale nood as enigste uitvoering van die kerk se sendingtaak hang saam met hierdie beginsel. Sendingwerk in die volste sin van die woord, word eers gedoen as kerke groei in lidmaattal en daar ook nuwe gemeentes gestig en vermenigvuldig word.

Om gemeentes te stig wat self weer die doel moet stel om nuwe gemeentes te stig is volgens Wagner “. . . the best evangelistic method under heaven" (Montgomery, 198?:22).

Winter formuleer dieselfde gedagte so: "The care and feeding of (new) congregations is thus to me the central strategic activity to which all gimmics (evangelistic methods) must be bent" (Montgomery, 198?:22).

Kommentaar

Met hierdie beginsel kan enige gereformeerde gelowige op Skrifgronde die hartlikste instemming betuig. Die leemtes van die genootskaplike sending wat nie gemeentes gestig het nie aan die een kant, en aan die ander kant die moderne ekumeniese benaderings wat sending laat opgaan in noodleniging, die verandering van politieke strukture en die nivellering van alle grense, word met die klem op kerkgroei te bowe gekom.

Peter Beyerhaus het reeds in 1974 aangetoon dat die ekumeniese benadering tot sending op die ou end die deur vir die teologie van die rewolusie oopgemaak het en niks anders gedoen het nie as om Marxisme en kommunisme te bevorder en daarom in wese eintlik die "mission of Barabas" is (Douglas, $1975: 299$ ).

Tog is dit jammer dat die "Church Growth Movement" nie die kosmiese dimensies van die versoeningswerk van Christus in berekening gebring 
het nie. Die skopus van Christus se versoeningswerk kan nie tot kerkgroei beperk word nie. Die diakonale roeping van die kerk as sendingwerk met die daad mag in die lig van bv. Matt $5: 13$ - 16 nie vergeet word nie. Skriftuurlike perspektiewe dat die kerk in die wêreld 'n unieke gemeenskap moet wees en 'n eskatologiese teken van die triomf van Christus, ontvang haas geen klem in die "Church Growth Movement" se denke nie.

\subsection{Fokus op eiesoortige kulturele groeperinge in kerkgroei}

"People movements", "Ethnic realities", en "Indigenous churches" is sleutelbegrippe vir McGavran en die "Church Growth Movement". Onder "People movements" word verstaan dat 'n bepaalde homogene groep mense in die geheel oorgaan tot die Christelike geloof.

McGavran sê: "A'People is a tribe or a caste, a clan or lineage, or a tightly knit segment of any society. A tribal movement of one single people of society" (McGavran, 1980:334).

Daar word beweer dat die Westerse kultuur in sy wese individualisties is, en daarom nie begrip het vir die moontlikheid dat 'n hele groep mense deur middel van ' $n$ "multi-individuele" beslissing tot geloof kan kom nie. Roger Greenway van die Christian Reformed Church in Noord-Amerika en professor in Sendingwetenskap by die Westminster Theological Seminary, meen dat die Bybelse verbondsgedagte - dat God sy kerk bou deur kettings van families en geslagte heen met hierdie beginsel van McGavran tot sy reg kom. Met instemming haal hy Harry R. Boer aan wat gesê het: "The great merit of McGavran in emphasizing the place of the oikos in missionary strategy can hardly be overestimated" (Conn, 1976:46).

McGavran beroep hom op die beroemde kerkhistorikus Latourette wat beweer het dat die kerk in die vroeg-Christelike tydperk juis deur middel van hele huishoudings en homogene groepe wat tot bekering gekom het, so vinnig in getalle toegeneem het. Ook die Reformasie van die sestiende eeu het volgens hom om dieselfde rede so vinnig oor Europa versprei en tweederdes van alle bekeerlinge van Asië, Afrika en Oseanië het volgens McGavran deur "people movements" tot geloof gekom.

Sy konklusie is duidelik: "The people movement is the God-given way by which resistance to the gospel is surmounted" (McGavran, 1980:336). Groepsbelange waaronder ook etnisiteit is Godgegewe brûe wat die oordra van die evangelie vergemaklik.

Niks is daarom volgens McGavran vir kerkgroei meer belangrik as om homogene eenhede te onderskei en die spesifieke karaktertrekke daarvan te onderskei nie. Kerke moet gestig word wat inspeel op die eiesoortige karaktertrekke van bepaalde homogene groepe. Volgens hom is 'n uiters belangrike wet vir kerkgroei die volgende: “ . . . discipling each homogeneous unit out to the fringes is more desirable as a rule, than establishing conglomorate congregations in many contiguous HUS" (Conn, 1976.40).

Omdat hierdie beginsel beteken dat iemand dan nie verplig is om sy eie homogene eenheid of kultuurgroep te verloen wanneer hy 'n Christen word nie, hou dit in dat hy 'n suiwer religieuse beslissing neem. Kerke wat uit 'n konglomoraat van homogene eenhede bestaan, is swak, omdat 
die konflikpotensiaal in so 'n kerk veel groter is en so 'n kerk groei ook stadig omdat elke oproep tot bekering ook impliseer om jou kulturele broers en susters te verlaat (Conn. 1976:40): McGavran, 1979:247 en cok Wagner. 1984 (a) : 127-143).

\section{Kommentaar}

McGavran het met hierdie beginsel inderdaad 'n belangrike korreksie op die Westerse individualisme van die "evangelicals" aangebring. Insig in die homogene groep en die sosiologiese dinamiek daarvan kan inderdaad lei tot sinvolle kontekstualisering van die evangelie en is daarom in alle sending- en evangeliseringswerk van groot belang. In hierdie verband kan met reg 'n beroep gedoen word op 1 Kor $9: 19-23$ en Fil $2: 4-8$, om kontekstualisering en sinvolle kommunikering van die evangelic te verciiep.

Tog moet daar al:yd gewaak word daarteen dat kontekstualisering nie lei tot sinkretisme nie. Daar moet altyd onthou word dat bepaalde kulturele gewoontes uitinge kan wees van 'n onchristelike lewens- en wëreldbeskouing. In die publikasies van McGavran en die "Church Growth Movement" kom bitter weinig tereg van die feit dat alle kulturele gewoontes altyd aan die kritiek van die evangelie onderworpe behoort te wees.

Die Bybelse kollektiewe gemeenskapskarakter van die verbond kan ook deur die toepassing van hierdie beginsel beter verdiskonteer word.

Tog mag die eweneens Bybelse persoonlike gemeenskapskarakter van die verbond nooit ontken word nie. Volgens die Skrif moet die kollektiewe gemeenskapskarakter van die verbond juis lei tot persoonlike gemeenskap tussen God en die gelowige voordat die verbond werklik sy doel bereik het (vgl. hieroor verder Buys, 1984:137-157).

John Young hel twee indringende vrae gevra wat nog nie deur McGavran en die "Church Growth Movement" na behore beantwoord is nie: "Have they been brought by a strategy or by the convicting power of the Holy Spirit? Have they substituted new rites for old with their faith still in externals and their sense of security still basically their tribal identity?"' (Conn, 1976:72).

Die probleem wat Young in verband met die "Church Growth Movement" se geweldige klem op homogeniteit in die kerk - as beginsel vir kerkgroei - ondervind, dui inderdaad vir die kerk van Christus 'n groot gevaar aan. Dit is dié groot gevaar dat mense aan die kerk behoort, maar hulle sekuriteit, veiligheid en geborgenheid ervaar in bepaalde kulturele tradisies sonder dat hulle werklik hulle anker in God self gevind het. Dan word homogeniteit 'n ideologie wat tussen die mens en God self te staan kom.

Dit is daarom nie geheel en al sonder grond dat McGavran gewaarsku is teen die belemmerende invloed wat die apartheidsideologie in sommige kringe in Suid-Afrika vir die kerk van Christus gehad het nie. Die kerk behoort immers altyd uit te gaan van die relatiewe waarde van kulturele tradisies. Robert Recker, sendingwetenskaplike van Calvin College, Grand Rapids, sê in hierdie verband: "I would contend that peoplehood is a historical development which is subject to change, and not to be viewed as ultimate in any sense. Certain representatives 
of South-African apartheid politics illustrate the consequences of ethnological divisions as creational givens and hence as expressions of the will of God which not only must be respected but also guarded" (Conn, 1976:76).

Daar moet altyd onthou word dat die kerk nie net in getalle moet groei nie, maar ook in sy vermoë om 'n omvattende verskeidenheid binne die eenheid te akkommodeer.

Van der Walt (1963:24) het reeds in 1963 in 'n ander verband in sy proefskrif gewaarsku dat "eiesoortige kerkvorming" nie mag uitloop op "kerklike apartheid" nie. Tog het lg. m.i. die probleem dat 'n verkeerde klem op "eiesoortige kerkvorming" in stryd kom met die universaliteit van die kerk, met sy antwoord dat elke plaaslike gemeente as volledige plaaslike openbaring van die liggaam van Christus beskou moet word en daarom die volheid van die universele kerk inhou, omseil (Van der Walt, 1963:331). Trouens, hy loop selfs die gevaar om van pragmatiese independentisme verdink te word wat hy aanwend om meer ruimte vir eiesoortigheid as 'n onveranderlike beginsel in te ruim.

\section{ALGEMENE OPMERKINGS}

Daar is bepaalde ondertone in die benadering van die "Church Growth Movement" wat ook ernstige aandag verdien.

\subsection{Skrifgebruik}

Die hele basiese benadering van die "Church Growth Movement", naamlik om kerkgroeiwette af te lei uit die ontleding van historiese situasies van groeiende of sterwende kerke (Wagner, 1984:43-46) is vir die Gereformeerde Teologie problematies. Die gevaar is lewensgroot dat die normatiewe gesag van die Skrif vir die bedieningsgestaltes van die Evangelie vervang word deur die positiewe resultate ten opsigte van getallegroeiaksies.

Natuurlik mag die waarde van ervaring nie ontken word in die motivering van keuses en vormgewing van metodes en bedieningsgestaltes nie, maar dan moet Skriftuurlike beginsels tog immers voorrang geniet. Die finale norm mag nooit wees of daar effektiewe groei gekom het nie, maar of bedieningsgestaltes wel Skriftuurlik verantwoord kan word.

Om kerke te motiveer om te reformeer ten opsigte van bedieningstrukture moet eerstens die toets van die Skrif aangelè word. Ondergeskik daaraan kdn wel van die hulpwetenskappe soos Psigologie, Sosiologie, Bedryfsbestuurswetenskappe ens. gebruik gemaak word om ook praktiese implementering van bedieningsbeginsels relevant te maak.

Die indruk ontstaan egter telkens dat die "Church Growth Movement" hierdie orde omkeer. Daarom is Skriftuurlike fundering dikwels uiters oppervlakkig, of word Skrifgedeeltes buite verband aangehaal om op die klank af bepaalde standpunte oor benaderings te motiveer, (Vgl. bv. die gebruik van die gelykenis van die onvrugbare vyeboom om die "Harvest Theology" te motiveer waarna hierbo verwys is.)

Per slot van rekening is baie kerke ten opsigte van sending en evangelisasie so oneffektief, nie maar omdat hulle metodes verkeerd is, al is hulle verder volledig Skrifgetrou nie, maar omdat hulle in vele opsigte afwyk van die Skrif self, wat betref die stel van prioriteite sowel as die 
keuse van metodes in die werk van die kerk. Aan die ander kant moet natuurlik baie goed onderskei word wanneer dit om beginsels gaan en wanneer om blote middelmatige praktiese aangeleenthede. Dit is wel waar dat middelmatige praktiese aangeleenthede (bv. eredienstye, of ligging van die kerkgebou of parkeerruimte), werklik struikelblokke kan wees in die weg van die bediening van die evangelie, maar dan is dit tog verwarrend om sulke sake te verhef tot die vlak van kerkgroeiwette en op die ou end daaraan meer aandag te spandeer as aan werklike Skriftuurlike beginselaangeleenthede.

Aan die positiewe kant moet erken word dat die benadering van die "Church Growth Movement" ons oë wawyd oopmaak vir die noodsaak daarvan dat ons teologiese aktiwiteit nooit blote teorie in 'n akademiese ivoortoring mag bly nie.

In sy evaluering van die "Church Growth Movement" ten opsigte van hierdie hele problematiek het J. I. Packer 'n verhelderende bydrae gelewer. "Evangelism and theology for the most part go separate ways, and the result is great loss for both. When theology is not held on course by the demands of evangelistic communication, it grows abstract and speculative, wayward in method, theoretical in interest and irresponsible in stance. When evangelism is not fertilized, fed and controlled by theology, it becomes a stylized performance seeking its effect through manipulative skills, rather than the power of vision and the force of truth. Both theology and evangelism are then unreal, false to their own God-given nature; for all true theology has an evangelistic thrust, and all true evangelism is theology in action" (Conn, 1976:91).

Daarom roep die "Church Growth Movement" na meer besinning om hierdie ideale van Packer oor teologie en praktiese gemeenteopbou te bereik. Die "Church Growth Movement" sal indringender na die Skrif self moet terugkeer, maar, die Gereformeerde teologie in Suid-Afrika kan beslis baat vind daarby om die praktiese werklikheid van ons tyd meer indringend te bestudeer ten einde die evangelie in al sy skoonheid en suiwerheid meer relevant te kan bedien aan die mense van ons tyd.

\subsection{Intieme verweefdheid tussen bewaring en vermeerdering van die kerk}

'n Besliste bate van die navorsing van die "Church Growth Movement" is dat die groot belang van die samehang tussen die bewaring en vermeerdering van die kerk aangetoon is. Dit is juis 'n siek kerk - wat nie groei in geestelike volwassenheid nie - wat ook nie groei in getalle nie. Dit is ook juis 'n kerk wat geen begeerte het om in getalle te groei nie wat 'n lou doodsheid in eie midde ervaar.

Te veel Gereformeerde kerke sien vermeerdering as 'n sydelingse stokperdjie vir enkele entoesiastiese gemeentelede, en besef nie dat getallegroel ook tot die sentrum van die kerk se bestaansdoelwitte moet behoort nie. Om suksesvol te evangeliseer moet die hele gemeente evangeliese bewoènheid openbaar sodat evangeliseringsaktiwiteite met alle ander gemeenteaktiwiteite in 'n sinvolle geheel geintegreer kan word. Die begrip "opbou" in die Nuwe Testament het die betekeniskomponente van sowel bewaring as vermeerdering. Kerke wat net op een van hierdie 
aspekte konsentreer sal ten spyte van sy konsentrasie nie sy doel bereik nie, omdat die een nie sonder die ander verkry kan word nie.

\subsection{Kerkbegrip: organisme of organisasie}

Die oppervlakkige Skriffundering en die eensydige toepassing van die sosiologiese wetmatighede op kerkgroei, skep soms die indruk dat die voorstanders van die "Church Growth Movement", die kerk van Christus te veel sien as 'n blote organisasie en te min as 'n organisme. Daarmee word bedoel dat Christus self en Hy alleen die Hoof van die Kerk is, dat elke lid van die liggaam persoonlik aan Hom deel het en dat dit veroorsaak dat kerklike strukture nie volledig met gewone organisatoriese strukture vergelykbaar is nie. Richards (1980 17) is daarom reg as hy beweer "If we are a body and Jesus is our head, then organizational structures and leadership functions should vary significantly from forms and functions appropriate to any other kind of organization ..."

\subsection{Geen plek vir funksionering van die ampte}

Die funksionering van die besondere dienste van ouderling en diaken word nie in die "Church Growth Movement" verdiskonteer nie. Daar word wel heelwat oor die algemeen gepraat oor die belang van gocie leierskap in die kerk. Wagner beskou dit selfs as een van die wette van kerkgroei dat die predikant van 'n groeiende kerk iemand moet wees wat die maksimum gesag uitoefen. Dit moet egter nie gesag wees wat hy formeel kragtens sy roeping en ampsposisie besit nie, maar gesag wat hy besit omdat hy met sy optrede in die gemeente soveel respek en waardering afgedwing het.

Die rede waarom 'n Bybelse ampsleer so min klem ontvang in die "Church Growth Movement" is waarskynlik omdat daar so min teologiese - veral eksegetiese - fundering gegee word en daarom te veel met ' $n$ kerkbegrip geopereer word wat meer sekulèr organisatories van aard is as wat dit Bybels organies is.

\section{ITEMS OP DIE AGENDA VAN DIE KERK}

Dit is maklik om die "Church Growth Movement" vanuit die Gereformeerde Dogmatiek te kritiseer en af te skiet. Veral die feit dat pragmatiese oorwegings soms meer die deurslag gee in die formulering van "kerkgroeiwette" as Skrifbeginsels, is problematies. Stellings soos dat 'n vereiste vir kerkgroei behels: "Find a need and fulfill it" (Wagner. 1984(a):96) maak die deur wawyd oop vir humanisme.

Aan die ander kant bewys die statistieke van die Gereformeerde Kerke in Suid-Afrika se sendingwerk soos wat dit na vore kom uit sinodale rapporte, dat daar tog by ons baie ruimte vir reformasie is. Myns insiens kan ons - op grond van Skriftuurlike fundering - gerus ons hartlike instemming met die volgende uitgangspunte van die "Church Growth Movement" betuig:

6.1 Dit is God se wil dat sy kerk sal groei in getalle. Die Gereformeerde leer oor verbond en uitverkiesing mag nooit 'n struikelblok wees vir praktiese sending- en evangeliseringswerk nie, maar moet juis dinamiese ywer vir getallegroei van die kerk stimuleer. God het dwarsdeur 
die Bybel ' $n$ missionêre doelwit met sy verbond. (Vgl. vir eksegetiese en openbaringshistoriese fundering hiervan Buys, 1984:106 e.v.)

6.2 Getallegroei is nie 'n kenmerk van 'n ware kerk nie. Ywer vir en verlange na getallegroei van die kerk is wel 'n kenmerk van 'n Skrifgetroue kerk. Dit is naamlik so dat die suiwere verkondiging van die Woord as merkteken van 'n ware kerk (NGB, art. 29) by die Reformatore, nie net slaan op die verkondiging in die kerkgebou nie, maar ook die uitdra van die Woord behels. Cliché's soos: "Dit maak nie saak as ons nie in getalle groei nie, solank as ons maar getrou is aan die suiwere leer ..." is 'n contradictio in terminis. Om getrou te wees aan die leer beteken tog juis ook om getrou te wees aan die bevel van Christus om uit te gaan en bekering en vergifnis van sonde in sy Naam aan alle mense sonder onderskeid te gaan verkondig. Daarom is Leslie Newbigin (1978:142) reg as hy sê: "Anyone who knows Jesus Christ as his Lord and Saviour must desire ardently that others should share that knowledge and must rejoice when the number of those who do is multiplied. Where this desire and this rejoicing are absent, we must ask whether something is not wrong at the very centre of the Church's life."

6.3 Die kerk moet natuurlike menseverhoudinge gebruik as brûe wat God in sy voorsienigheid gegee het vir die verstaanbare kommunikering van die evangelie. Hier kan sosiologie, psigologie en kommunikasiekunde sinvol as hulpwetenskappe by die missiologie gebruik word.

6.4 Deur indringende voortgesette navorsing, deur analise van eie effektiwiteit en analise van die gemeenskap waarin die evangelie uitgedra word, moet die kerk gereeld hand in eie boesem steek.

6.5 Die amp van die gelowige moet veel meer as wat tans in die reël die geval is gemobiliseer word in die getuienistaak van die kerk.

6.6 Die gebruik van statistieke, doelwitbeplanning, die ontwikkeling van Bybelsgefundeerde leierskap deur die identifisering en implementering van gelowiges se gawes in die kerk, is onmisbaar vir sinvolle georganiseerde evangelisasie en sendingprojekte. Die effektiwiteit van projekte kan so sinvol geëvalueer word.

\section{KONKLUSIE}

Ten spyte van die soms oppervlakkige eksegetiese en teologiese fundering, die neiging tot goedkoop pragmatisme en die soms simplistiese formules, kan baie van die "Church Growth Movement" geleer word. Indien die standpunte van die "Church Growth Movement" ons weer terugdwing na die Skrif om ons opnuut te verantwoord oor wat praktiese kerkwees behoort in te hou, is die bestudering van hierdie beweging beslis die moeite werd. Indien dit ons bring tot eerlike evaluering van ons eie kerkwees, kan reformasie op hierdie manier gestimuleer word.

\section{BIBLIOGRAFIE}

Anon. 1982. Kerkboden, Nedl. Gereformeerde Kerken, 38/1, 1982-10-09.

Buys. P. J. 1984. Die aard van die verbond en die implikasies daarvan vir Evangelisasie

Potchefstroom: PU vir CHO. (Ongepubliseerde) Th.M -verhandeling 


\section{6 - In die Skriflig}

Conn. H M. (red ) 1976. Theological perspectives on Church Growth Phillipsburg: Presbyterian and Reformed Pub. Co

De Wet. C. R 1986. The Church Growth movement does it foster churches to challenge the world? in Missionalia Vol. 14 No. 2 (Augustus 1986) 85-100)

Douglas. J. D. (red.) 1975. Let the earth hear his voice. International Congress on World Evangelization. Lausanne, Switzerland. Minneapolis: World Wide Publ.

Gibbs, E 1981 I believe in church growth. London: Hodder \& Stoughton

Hart. D J. 1987. Does the church count? A position paper for (hristian Reformed Home Missions. Ongepubliseerd

Krol, B 1982. Gemeentegroei - kenmerken van groeiende en kwijnende gemeenten. Amsterdam: Buijten \& Schipperheijn.

McGavran, D. A 1955. The bridges of God London: World Dominion Press. (red.) 1965. Church growth and Christian mission. London: Ilarper \& Kow (red.) 1972. Crucial issues in missions tomorrow. Chicago: Moody Press 1979. Ethnic realities and the church; lessons from India. Pasadena : William ('arey Library

en Arn W. C. 1973. How to grow a church. Glendale: California G/L Publ en Arn W. C. 1977. Ten steps for church growth San Francisco: Harper \& Row rev. ed. 1980. Understanding church growth. Grand Rapids. Eerdmans 1968. Will Uppsala betray the two billion? Church Growth Bulletin, vol. IV nr 5 (Mei $1968)$.

Montgomery. J. 198? The principles and practice of Dawn. A growing movement for world evangelization. Ongepubliseerde werkstuk.

Newbigin, L. 1978. The Open Secret. Grand Rapids: Eerdmans

Packer. J. I. 3e d. 1965. Evangelism and the sovereignty of God. I.ondon: Inter-varsity Fellowship

Richards, L. O. \& Hoeldtke, C. 1980. A Theology of Church Leadership Grand Rapids Zondervan Publ. House.

Saayman, W. A. The Church Growth movement: an appropriate challenge? A response to Chris de Wet. in Missionalia Vol. 14 No. 2. (Augustus 1986) 100-103.

Smith, E. C. 1984. Balanced Church Growth. Church Growth based on servanthood. Tennessee: Broadman Press.

Son, Y. J. 1983. The Missiological significance of Matthew $28: 16-20$ with special reference to Donald M. McGavran. Potchefstroom: PU vir CHO. (Ongepubliseerde) Th.D. proefskrif.

The USCenter for World Mission. 198? Imagine . . A Church for Every People by the Year 2000 Pasadena: US Center for World Mission.

Van der Walt. I. J. 1963. Eiesoortigheid en die sending. Eiesoortige kerkvorming as missiologiese probleem met besondere verwysing na Suid-Afrika. Potchefstroom: Pro Rege. 1982. Evangelisasie: 'n Uitdaging vir die Gereformeerde Kerk. Ongepubliseerde referaat gelewer tydens 'n Evangelisasiekonferensie te Pretoria in Oktober 1982. 1985. Die Evangelie aan Afgedwaaldes. Handleiding vir Evangelisasie. Potchefstroom: Universum.

Wagner, C. P. 1971. Frontiers in missionary strategy. Chicago: Moody Press. 1971. Who found it? in Eternity (Sept. 1977) 13-19. 2e dr. 1984a. Your Church can grow. Seven signs of a healthy church. Ventura: Regal Books. 1984. Leading your church to growth. Ventura: Regal Books.

Winter, R. 1975. The Highest Priority: Cross-cultural Evangelism. in Douglas. J. D. (red.) 1975. Let the earth hear his voice. International Congress on World Evangelization, Lausanne, Switzerland. Minneapolis: World Wide Publ. 